\title{
17. STABLE ISOTOPE RECORDS FROM SITES 932 AND 933
}

\author{
M. Maslin, ${ }^{2,3}$ S. Burns, ${ }^{4}$ H. Erlenkeuser, ${ }^{5}$ and C. Hohnemann ${ }^{2}$
}

\begin{abstract}
The Amazon Fan is an excellent area to obtain the climatic records of the last glacial-interglacial cycle. Glacial sedimentation rates ranging from $1 \mathrm{~m}$ to over $50 \mathrm{~m} / \mathrm{k}$.y. provide an opportunity to obtain marine records approaching the resolution of the Greenland ice cores. Ocean Drilling Program (ODP) Leg 155 Sites 932 and 933 from the eastern, mid-Amazon Fan complex have been studied initially at a resolution of $50 \mathrm{~cm}(100-400 \mathrm{yr}$ per sample). The identification of paleomagnetic excursions, distinctive patterns in the paleomagnetic remanence intensity records, and radiocarbon dates have provided an age framework for both Sites 932 and 933. However, it was only possible to construct a detailed age model for Site 932. Planktonic foraminiferal stable oxygen and carbon isotope records of six species were obtained for both sites.

The planktonic foraminiferal carbon isotope records of both Sites 932 and 933 show a distinct negative deviation during Termination I (13-15 calendar ka). We suggest this could have been caused by an increase in the sediment discharge of the Amazon River because of the deglaciation of the Andes and/or the release of significant quantities of gas hydrates as large parts of the Amazon Fan sediment column fail because of increased sea level. Positive deviations occur in the composite Site 932 oxygen isotope record, the timing of which seems to coincide with the Heinrich events of the high latitude North Atlantic. However, there are considerable doubts over the validity of the composite record, the Site 932 age model, and the possible affects of reworking.
\end{abstract}

\section{INTRODUCTION}

The Amazon Fan has developed since the early Miocene, because of the massive increase in the sediment transport of the Amazon River following the Andean uplift (Carneiro de Castro et al., 1978; Hoorn et al., 1995; Curry, Shackleton, Richter, et al., 1995). At present, and during other interglacial periods, the Amazon River terrigenous sediments are deposited predominantly on the inner continental shelf (Flood, Piper, Klaus, et al., 1995). Only pelagic sediments, therefore, accumulate on the Amazon Fan during interglacial periods. During glacial periods, the lower sea level causes the outflow of the Amazon River to shift to the northeast, allowing sediment to feed directly into the Amazon Submarine Canyon, and hence into the fan complex (Damuth and Fairbridge, 1970; Damuth and Kumar, 1975). Changing sea levels thus control the sedimentation regime of the Amazon Fan. It has also been suggested that rapid changes in sea level destabilized the shelf and the Amazon Fan sediments, causing the many masstransport deposits found in the Amazon Fan (Maslin and Mikkelsen, this volume).

This switching on and off of terrigenous sediment supply to the Amazon Fan has a major impact on sedimentation rates. On average, the sedimentation rates for the Holocene are similar to open ocean rates, $\sim 2$ to $5 \mathrm{~cm} / \mathrm{k} . y$., whereas the glacial sedimentation rates range from 1 to $>50$ m.y., at least three orders of magnitude greater than interglacial rates (Mikkelsen and Maslin, this volume). The glacial sediments of the Amazon Fan thus provide us with unique opportunities

${ }^{1}$ Flood, R.D., Piper, D.J.W., Klaus, A., and Peterson, L.C. (Eds.), 1997. Proc. ODP, Sci. Results, 155: College Station, TX (Ocean Drilling Program).

${ }^{2}$ Geologisch-Paläontologisches Institut, Universität Kiel, Olshausenstrasse 40, 24098 Kiel, Federal Republic of Germany.

${ }^{3}$ Current address: Environmental Change Research Centre, Department of Geography, University College London, 26 Bedford Way, London WC1H 0AP, United Kingdom. MMaslin@geog.ucl.ac.uk and

${ }^{4}$ Geologisches Institut, Universität Bern, Baltzerstrasse 1, CH-3012, Bern, Switzer-

${ }^{5}$ C-14 Laboratory, Department of Physics, Universität Kiel, 24098 Kiel, Federal Republic of Germany. to study past climate. First, the sedimentation rates are so high that it becomes possible to obtain ocean records with a resolution approaching that of the Greenland ice cores (Dansgaard et al., 1993), that is, a decadal resolution. Second, it is possible to monitor changes of climate, hydrology, and vegetation of the Amazon Basin during the last glacial (e.g., the pollen work by Haberle, this volume, and Hoorn, this volume), as well as climate and circulation changes of the western equatorial Atlantic. The high sedimentation rates, however, also make the Amazon Fan sediments a challenge, because the very dynamic nature of deep-sea fans makes them notorious for being influenced by reworking. The major concerns are local slumping, flows, turbidites, and erosion, as well as deposition of older material from higher up the Amazon Fan complex and from the continental shelf and slope. Great care is therefore required when choosing site locations and when interpreting the results, although previous work has demonstrated that good climatic records can be obtained from the Amazon Fan, despite these drawbacks (e.g., Damuth, 1975, 1977; Showers and Bevis, 1988).

One of the key paleoceanographic objectives of Leg 155 was to try to utilize the exceptional sedimentation rates to obtain high resolution climate records to investigate interglacial-glacial changes in the circulation of the western equatorial Atlantic Ocean. This is because a key component of the North Atlantic Ocean heat and salinity budget originates in the southwest Atlantic Ocean. The North Brazil Coastal Current (NBCC) is the only surface water current known to cross the equator, exporting both heat and salinity to the North Atlantic (Metcalf and Stalcup, 1967; Richardson and Walsh, 1986). From December to June, when wind stress variation causes an increase in the NBCC transport, the NBCC may extend into the Guyana Current, which links in with the Caribbean Current (Picaut et al., 1985; Philander and Pacanowski, 1986). The NBCC can, therefore, influence the temperature and salinity of both the Caribbean and the Gulf of Mexico, the sources of the Florida Current and the Gulf Stream (Levitus, 1982). The potential downstream effect of this is that the crossequatorial transport of the NBCC can ultimately affect the characteristics of the surface waters reaching the Nordic Seas, and thus of the deep water formed there. Between July and November, the NBCC 


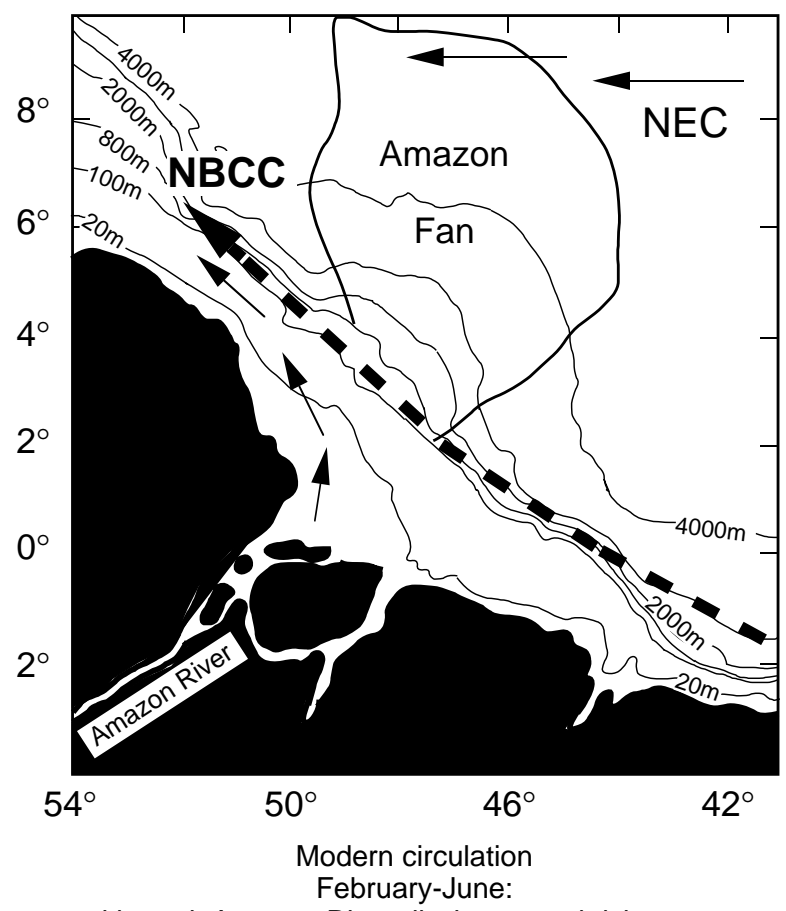

with peak Amazon River discharge and rising water

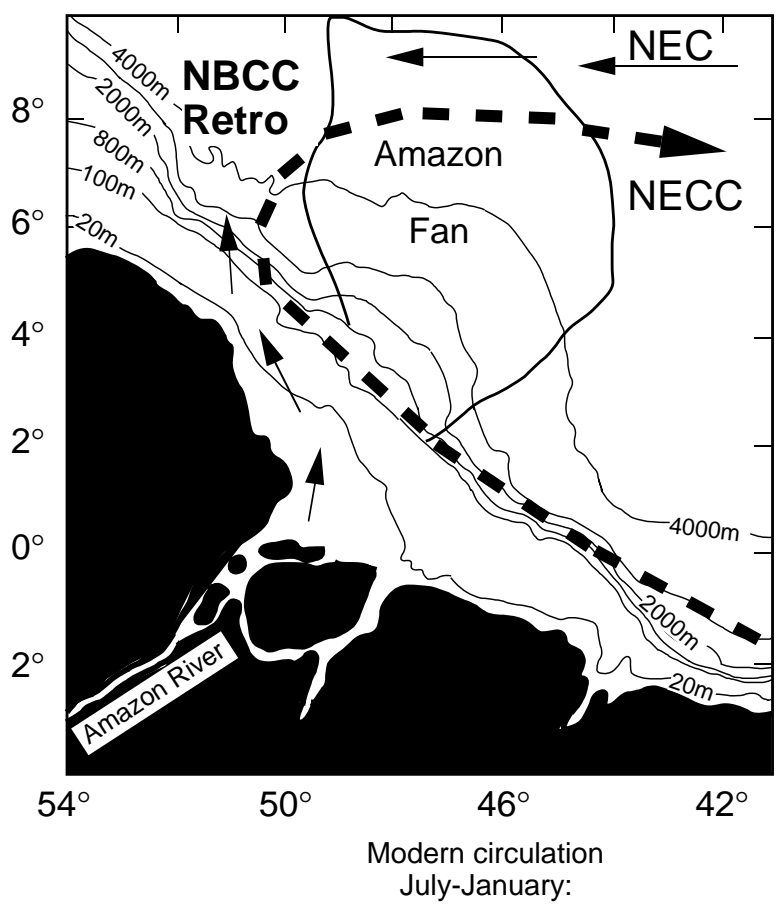

with minimum Amazon River discharge and falling water

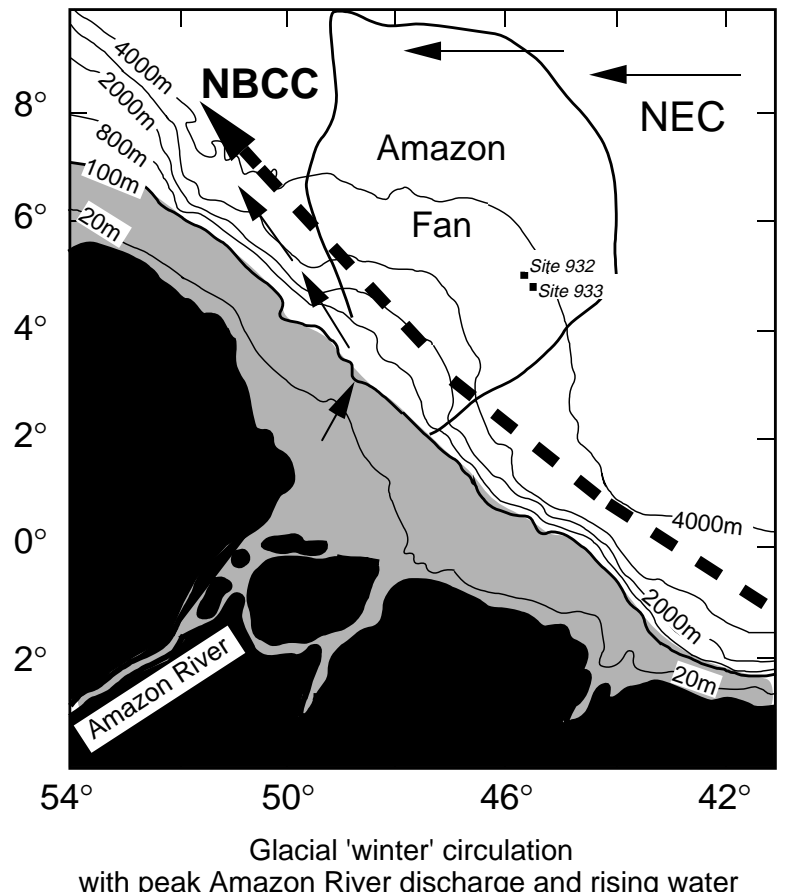

with peak Amazon River discharge and rising water

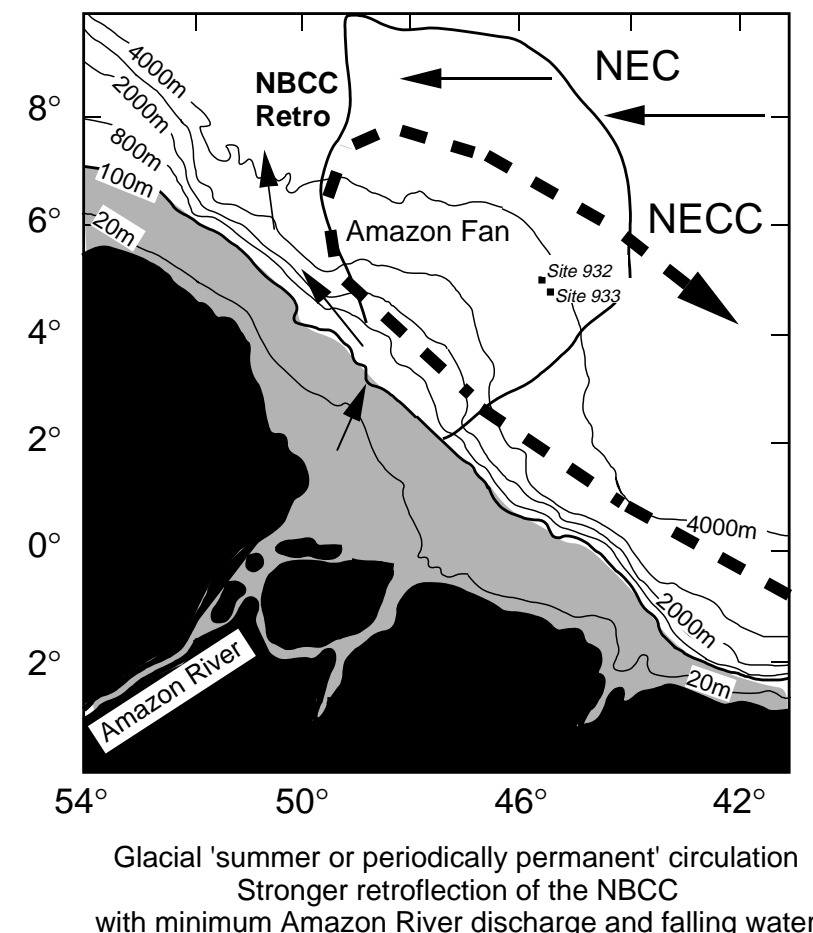

with minimum Amazon River discharge and falling water

Figure 1. Sketch map showing the present day and the possible glacial seasonal variation in the surface circulation of the western equatorial Atlantic. This study suggests that the retroflection of the NBCC may have had a longer seasonal occurrence when compared with the modern circulation during the last glacial. During some periods, it may have been permanent. Note that the glacial coastline of Brazil has been moved to the 100-m contour line due to the lower sea level. $\mathrm{NBCC}=$ North Brazil Coastal Current, NEC $=$ North Equatorial Current, NECC $=$ North Equatorial Counter-Current, and NBCC Retro $=$ retroflection of the NBCC. 
turns eastward (retroflects) into the eastward-flowing North Equatorial Counter-Current (NECC), switching off this cross-equatorial transport (Fig. 1).

Lenses of low-salinity surface water resulting from the input of freshwater from the Amazon River can occasionally become detached and move seaward, perhaps as a result of weakened trade winds, NECC eddies, or variations in Amazon River discharge (Nittrouer and DeMaster, 1986). During low sea-level stands, the Amazon River would have discharged directly into relatively deep water, and mixing of the river plume into the coastal water might have occurred more slowly than at present, allowing the build-up of more extensive freshwater lenses. Planktonic foraminifer oxygen isotope records from piston cores recovered on the eastern Amazon Fan, have indicated a number of well-developed negative deviations during the late glacial and early Holocene. These have been interpreted as evidence of Amazon River paleo-discharge events (Showers and Bevis, 1988). Such deviations seem to be less common on the western part of the fan, suggesting they may instead represent reduced activity of the NBCC. These isotopic events potentially represent periods of reduced cross-equatorial ocean heat and salt transport, both important components of global oceanic circulation.

The aim of this study was to produce high-resolution stable isotopic records for the last glacial from the Amazon Fan to investigate: (1) the occurrence of planktonic foraminifer oxygen and/or carbon isotope deviations; and (2) Amazon River discharge and the circulation of the equatorial western Atlantic Ocean.

\section{SITE SELECTION}

Leg 155 drilled 17 sites on the Amazon Fan (Fig. 2). The selection of the sites was based on the multiple aims of the leg, see Flood, Piper, Klaus, et al. (1995). Sites $932\left(5^{\circ} 12.7^{\top} \mathrm{N}, 47^{\circ} 1.8^{\prime} \mathrm{W}\right.$, water depth $3334 \mathrm{~m})$ and $933\left(5^{\circ} 5.8^{\circ} \mathrm{N}, 46^{\circ} 48.7^{\prime} \mathrm{W}\right.$, water depth $\left.3366 \mathrm{~m}\right)$ were selected for this stable isotope study for the following reasons: (1) both sites in the shallower sections contain levee mud sequences making them suitable for paleoceanographic studies; (2) the sites have glacial sedimentation rates high enough to provide high resolution records with a time resolution of between 100 and $400 \mathrm{yr}$ at the initial $50-\mathrm{cm}$ sampling intervals; (3) the sedimentation rates are also low enough that planktonic foraminifers can be found in sufficient quantities for stable isotope analysis; and (4) the sites are $\sim 25 \mathrm{~km}$ apart at a similar water depth, therefore making it possible to verify isotope excursions by comparing the records of the two sites. This is important, as one of the aims of this study is to investigate short intense climatic changes. A key problem with Amazon Fan sediments is that climatic records can contain features that appear to be significant "events," but are actually due to reworking, especially turbidites.

\section{METHODS}

Samples of $20 \mathrm{~cm}^{3}$ were taken aboard ship approximately every $50 \mathrm{~cm}$. Care was taken not to take samples from disturbed sections or areas identified as turbidites (Flood, Piper, Klaus, et al., 1995). The samples were freeze dried and then wet sieved through a $63-\mu \mathrm{m}$ mesh sieve. The samples were then dry sieved at discrete intervals between 250 and $400 \mu \mathrm{m}$, depending on which planktonic foraminifer species were picked. The oxygen and carbon isotopes of the planktonic foraminifers were measured using a Finnigan MAT 251 mass-spectrometer at Kiel University. The Kiel laboratory uses a Carbo-Kiel preparation line, that is an automated system where acid is added to individual samples and reacted at $90^{\circ} \mathrm{C}$. The analytical reproducibility based on replicate measurements of an internal laboratory standard is $\pm 0.04 \%$ or for $\delta^{13} \mathrm{C}$ and \pm 0.07 for $\delta^{18} \mathrm{O}$. All results were calibrated to the

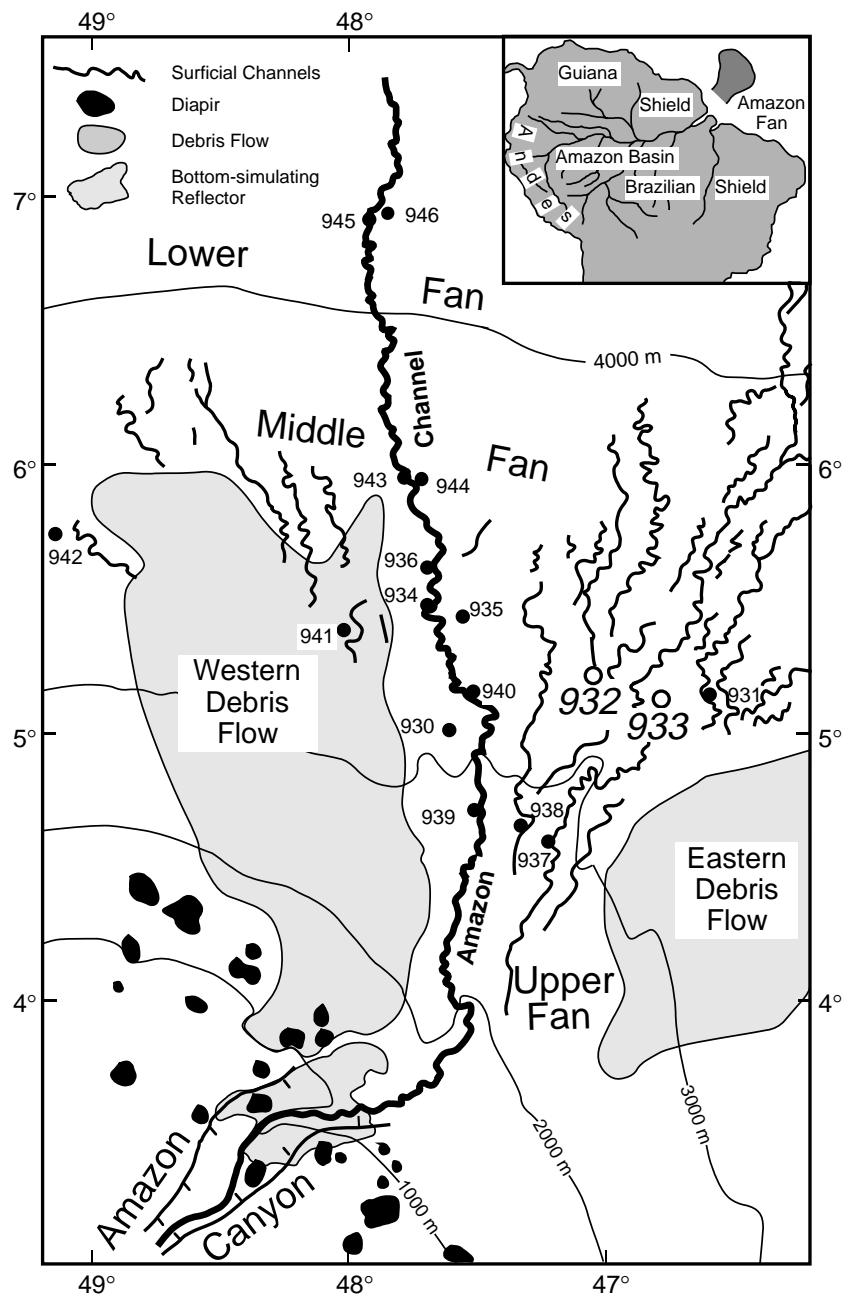

Figure 2. Location map of the Amazon Fan sites. Modified from Flood et al., 1995; modified from Damuth et al., 1988, and Manley and Flood, 1988.

Peedee Belemnite (PDB) scale, using the National Bureau of Standards (NBS) 19 standard. In many cases, the lack of calcium carbonate because of the dilution effects by the extremely high sedimentation rates $(1-50 \mathrm{~m} / \mathrm{k} . \mathrm{y}$.) resulted in very few specimens being measured (no sample of less than six specimens were run). The gas pressure from the mass spectrometer was thus checked to make sure there was sufficient material for a reliable measurement. Listed below are six planktonic foraminifer species that were analyzed, and the discrete size fraction the specimens were picked from: Globigerinoides ruber $(250-300 \mu \mathrm{m})$, G. trilobus $(300-350 \mu \mathrm{m})$, G. sacculi-

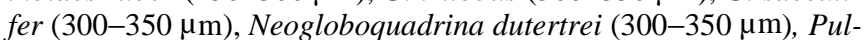
leniatina obliquiloculata $(350-400 \mu \mathrm{m})$, and Globorotalia truncatulinoides $(300-350 \mu \mathrm{m})$. These six species were chosen primarily for their relatively high abundance in the Amazon Fan sediments (Flood, Piper, Klaus, et al., 1995), and also because they represented a range of water depths from the near-surface dwellers down to thermocline dwellers. Moreover, the number of foraminifer species and specimens varied greatly throughout Sites 932 and 933 sediments because of the large fluctuations in sedimentation rate and subsequent dilution by terrestrial sediment. By analyzing all the key planktonic species, however, it may be possible to obtain a composite isotopic record for the last glacial. It should be noted that variations in both the number of planktonic foraminifers per sample and the low number of speci- 
mens per sample can be sources of considerable error (Trauth, 1995; Maslin and Hall, unpubl. data). The extreme sedimentation rates of the Amazon Fan, however, negate there being any bioturbation effects. Yet, the greatest problem with interpreting any isotopic record recovered from the Amazon Fan, is isolating the effects of turbidites and general reworking.

\section{AGE MODELS}

One of the major challenges of trying to reconstruct past climates from fan sediments is building a reliable age model. Unfortunately, the sediments at Sites 932 and 933 have so few foraminifers that detailed accelerator mass-spectrometry (AMS) ${ }^{14} \mathrm{C}$ dating was not possible. The age models of Sites 932 and 933 were, thus, primarily based on paleomagnetics. Conventional magnetic stratigraphy of the Leg 155 Amazon Fan sediments was not possible because of the relative young ages of the sediments recovered ( $<460 \mathrm{ka}$, Mikkelsen and Maslin, this volume). It has, however, been possible to take advantage of the very high Amazon Fan sedimentation rates and to use several other less-utilized magnetostratigraphic techniques (Cisowski and Hall, this volume). These include identification of short periods of anomalous geomagnetic polarity (i.e., events and excursions) in the archive-half magnetic remanence record and the recognition of distinctive patterns in the magnetic remanence intensity.

The Lake Mungo Excursion was first identified from early hominid Australian fireplaces dated at 32 calendar ka. The excursion consists of a very large increase in field strength and a migration of the apparent geomagnetic pole toward the equatorial South Pacific (Merrill and McElhinny, 1983). The Lake Mungo Excursion has been identified by a peak in relative intensity and inclination in both Holes 932A and 933A, and this has been confirmed in discrete samples by Cisowski and Hall (this volume). A second "older" excursion has been identified from shipboard records and discrete samples in Hole 932A (Cisowski and Hall, this volume), and this is believed to be the Laschamp Excursion (43 calendar ka).

Distinct patterns in the archive-half remanence curve were identified aboard ship (Flood, Piper, Klaus, et al., 1995). Since the archive core measurements were not normalized to any laboratory induced remanence, it was not clear at the time whether these reoccurring patterns were due to synchronous changes in sediment character across the fan, or whether they were primarily related to changes in the strength of the geomagnetic field. Subsequent discrete sample shorebased work by Cisowski and Hall (this volume) confirms that the remanence intensity variations do reflect temporal variations in the geomagnetic field strength. Cisowski and Hall (this volume) have successfully identified 12 intensity features in the Amazon Fan sediments (Table 1). The identifications of these intensity features for Holes 932A and 933A are shown in Flood, Piper, Klaus, et al. (1995, "Site 933" chapter, fig. 15). Using oxygen isotope stratigraphy and radio-carbon dating, Tric et al. (1992) were able to date changes in the "stacked" paleo-remanence intensity records of four Mediterranean cores. By careful comparison of the Amazon Fan remanence intensity records to those of Tric et al. (1992), Cisowski (1995) has estimated the date in calendar years of each of these events.

It was possible to obtain enough planktonic foraminifers to AMS ${ }^{14} \mathrm{C}$ date three samples from Hole 932A. These samples were dated at the new Leibniz Labor für Altersbestimmung und Isotopenforschung, Kiel University, Federal Republic of Germany. The ages are given as conventional ${ }^{14} \mathrm{C}$ ages calculated with a $5568 \mathrm{yr}$ Libby halflife. The results were corrected for sample preparation contamination by subtracting the activity measured in Eemian foraminifers processed in the same way. A general ocean reservoir correction of -400 yr has been made, though it is noted that this may differ both because of location and changes in the rate of deep water ventilation in the past. The first sample $(155-932 \mathrm{~A}-1 \mathrm{H}-1,19-24 \mathrm{~cm}, 0.19$ meters be-
Table 1. Age control points.

\begin{tabular}{lccc}
\hline \multirow{2}{*}{$\begin{array}{c}\text { Paleomagnetic remanence } \\
\text { intensity features }\end{array}$} & \multirow{2}{*}{$\begin{array}{c}\text { Age } \\
\text { (ka) }\end{array}$} & \multicolumn{2}{c}{ Hole depth (mbsf) } \\
\cline { 4 - 5 } & & $932 \mathrm{~A}$ & $933 \mathrm{~A}$ \\
\hline Peak A & 9 & $5^{*}$ & 4 \\
Peak B & 17 & $8^{*}$ & $12(?)$ \\
Peak C & 26 & $15^{*}$ & 25 \\
Peak D & 27 & $18^{*}$ & $35(?)$ \\
Peak E & 30 & $22^{*}$ & $45(?)$ \\
Low L1 & 39 & $26-28(?)$ & $?$ \\
Peak F & 42.5 & $30(?)$ & $?$ \\
Peak G & 49 & $35^{*}$ & $?$ \\
Peak H & 54 & $40^{*}$ & $?$ \\
Low L2 & 66 & $44^{*}$ & $?$ \\
Peak I & 68 & $45^{*}$ & $?$ \\
\hline \multicolumn{1}{c}{ Paleomagnetic } & Age & Hole depth (mbsf) \\
\cline { 4 - 5 }$\quad$ excursions & $(\mathrm{ka})$ & $932 \mathrm{~A}$ & $933 \mathrm{~A}$ \\
\hline Lake Mungo & 32 & $26^{*}$ & 82 \\
Laschamp & 43 & $27.5^{*}$ & $?$ \\
\hline
\end{tabular}

Notes: $*$ age control points selected for the $932 \mathrm{~A}$ age model used in this study. The above data are based on paleomagnetic remanence intensity features, the dates of which are based on Tric et al. (1992), and paleomagnetic excursions, the dates of which are based on McHargue et al. (1995).

low seafloor [mbsf]) was chosen to date the top of Hole 932A, and consisted of $2000 \mathrm{G}$. trilobus tests in the $>350-\mu \mathrm{m}$ size range. This sample gave an age of $3970 \pm 90 \mathrm{yr}$, and confirms that a significant part of the Holocene was recovered at Site 932. The second sample (155-933A-1H-1, 70-74 cm, 0.70 mbsf) was chosen to date the top of Hole 933A, and consisted of $1500 \mathrm{G}$. trilobus tests in the $>250 \mu \mathrm{m}$ size range. This sample gave an age of $11,910 \pm 90 \mathrm{yr}$ and suggests that at least some of the Holocene was recovered at Site 933. The third sample (155-932A-3H-6, 20-24 cm, $23.20 \mathrm{mbsf}$ ) was chosen to confirm the dating and identification of the Lake Mungo Excursion in Hole 932A and consisted of 1350 tests that were a mixture of $N$. dutertrei and $G$. truncatulinoides in the $>250 \mu \mathrm{m}$ size fraction. This final sample gave an age of $32,730+320 /-300$ yr. Despite the low number of tests and the necessity of using more than one species, the AMS ${ }^{14} \mathrm{C}$ date does confirm that the Lake Mungo Excursion (24.9 mbsf) has been correctly identified.

One biostratigraphic datum was identified in Hole 932A, the disappearance of the planktonic foraminifer P. obliquiloculata (Figs. 3, 4) at about 40 ka (Flood, Piper, Klaus, et al., 1995). However, the identified $P$. obliquiloculata datum in Hole 932A does not agree with the dates provided by the paleomagnetic remanence intensity features. In fact, the last $P$. obliquiloculata test is found $10 \mathrm{~m}$ below where it would be predicted to occur. This could the be the result of the following: (1) the P. obliquiloculata datum is diachronous across the equatorial Atlantic and may vary between 35 and $50 \mathrm{ka}$ (Prell and Damuth, 1978; Flood, Piper, Klaus, et al., 1995; R. Schneider, pers. comm., 1995); (2) the disappearance of $P$. obliquiloculata indicates very low numbers of planktonic foraminifers present in the glacial sections of Site 932, as P. obliquiloculata usually makes up less than $5 \%$ of the glacial equatorial Atlantic planktonic foraminiferal assemblage. This may be further compounded by the rapid changes of sedimentation rates, so that the disappearance of $P$. obliquiloculata in Hole 932A may be the result of dilution rather than climate; or (3) the remanence intensity features may be incorrectly identified or dated.

The age models of Holes 932A and 933A were constructed by linearly interpolating between the age points identified by the remanence intensity features and the Lake Mungo and Laschamp Excursions (Fig. 3). The dating of Hole 933A is extremely weak because of (1) the difficulty in identifying the remanence intensity features; (2) the conflict between the magnetic remanence intensity feature $\mathrm{A}$ and the AMS ${ }^{14} \mathrm{C}$ date for the top of the core; and (3) the fact that the continuous sediment record of Site 933 is curtailed by the deep Eastern Mass-Transport Deposit (EMTD). By extrapolating the sedimenta- 


\section{Estimated age (calendar ka)}

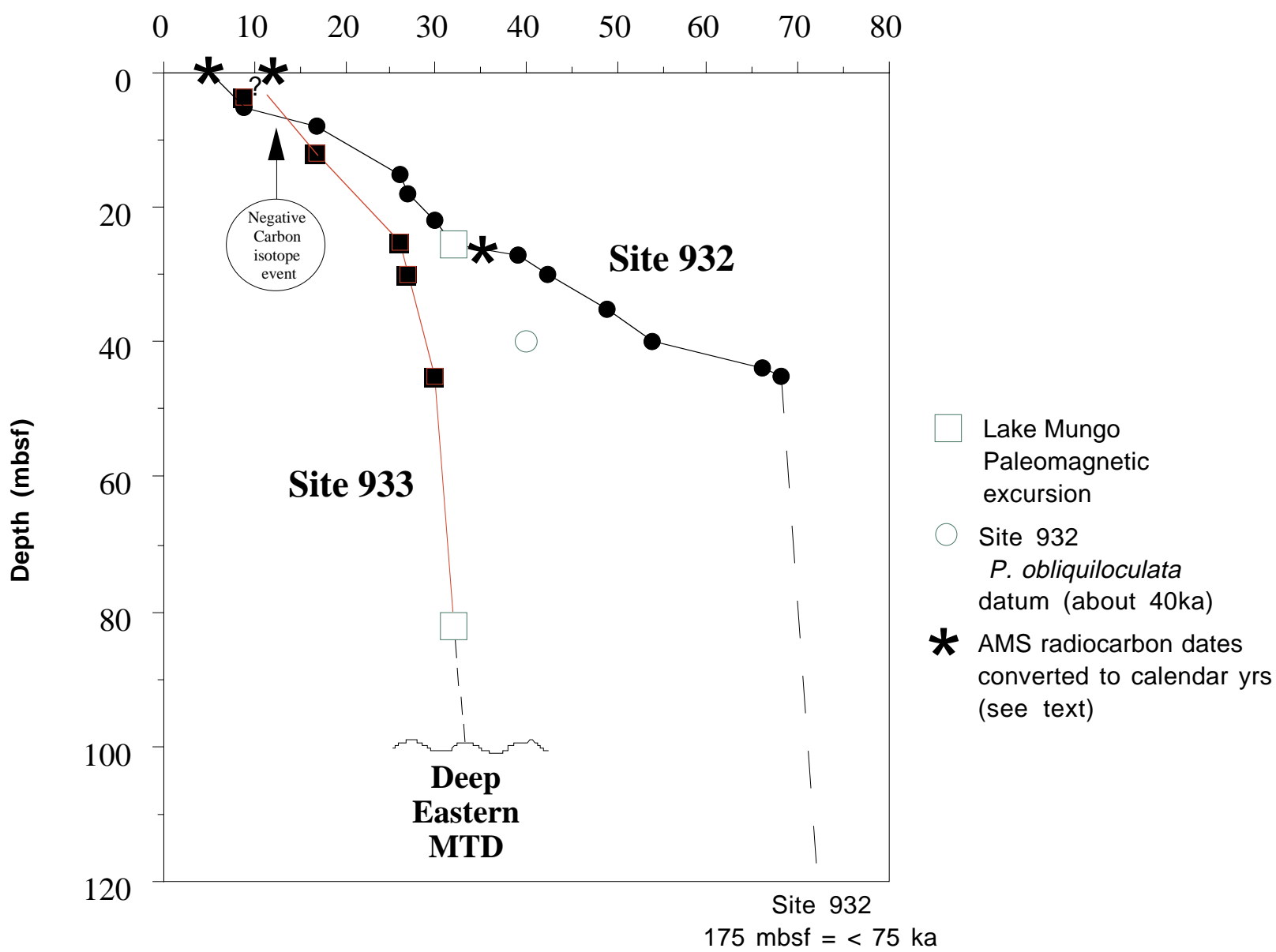

Figure 3. Age (calendar ka) vs. depth (mbsf) plot for Sites 932 and 933, illustrating the paleomagnetic-based age model for each site (see Table 1), the AMS ${ }^{14} \mathrm{C}$ dates converted to calendar years (see text), and the P. obliquiloculata datum identified in Site 932.

tion rate above the Lake Mungo Excursion identified in Hole 933A, it seems the top of the deep EMTD is no older than $33 \mathrm{ka}$. Because of the difficulty of dating Hole 933A, presently no attempt has been made to construct an age model for this site.

The age model for Hole 932A is better constrained, as nine remanence intensity features and two excursions have been identified. The Holocene AMS ${ }^{14} \mathrm{C}$ date was converted to calendar years using the method outlined in Sarnthein et al. (1994) and used to constrain the top of the age model. The deepest intensity feature identified in Site

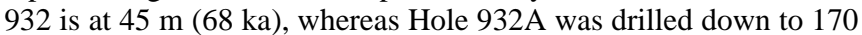
mbsf. Biostratigraphic evidence (i.e., the absence of the G. menardii complex; Mikkelsen and Maslin, this volume), suggests that the base of Hole $932 \mathrm{~A}$ is younger than $85 \mathrm{ka}$, which would place the base of Site 932 into the end of the last interglacial or the beginning of the last glacial. Sedimentological and seismic work suggests that the sediment between 47 and 170 mbsf, Unit IIb, is of a very similar character, mainly silty clay, and is part of a levee crest of the Channel-levee System 6B. These results are confirmed by the organic chemistry of the sediments, which from the carbon isotopes of total organic carbon and the lignin concentrations, indicate that all the organic carbon in Unit IIb is terrestrial, which is characteristic of last glacial Amazon Fan sediments (Goñi, this volume). Therefore, the base of Site 932 can be no older than $75 \mathrm{ka}$, which would suggest a sedimentation rate of over $18 \mathrm{~m} / \mathrm{k}$.y. This is consistent with the lack of planktonic fora- minifers within the sediments. Within the Amazon Fan, there is usually an indicator of diluted, massive amounts of terrestrial material. Also, the sedimentation rate is similar to that found in the adjacent Site 933 below a depth of 25 mbsf (Fig. 3).

\section{RESULTS}

\section{Site 932}

The planktonic foraminifer oxygen and carbon isotope records for the top $60 \mathrm{mbsf}$ from Hole 932A are shown vs. depth in Figures 4 and 5. Fairly complete records have been obtained for G. ruber, G. trilobus, N. dutertrei, and G. truncatulinoides; only between 29.5 and $31.0 \mathrm{mbsf}$ were the occurrences of all planktonic foraminifers so low that no isotope analyses were possible. The top two samples, at 0.19 and $0.74 \mathrm{mbsf}$, have interglacial-type oxygen isotope values and represent the low sedimentation rate Holocene sediments, whereas samples from all other depths have heavy glacial-type oxygen isotope values (Fig. 4). The P. obliquiloculata isotope record is curtailed by its disappearance from the equatorial Atlantic at $\sim 40 \mathrm{ka}$, although it reappears at about $11 \mathrm{ka}$. The isotope records of $G$. sacculifer and $G$. truncatulinoides are patchy, because of the low overall abundance of planktonic foraminifers and their low percentage occurrence within the glacial planktonic foraminifer assemblage. The most significant 


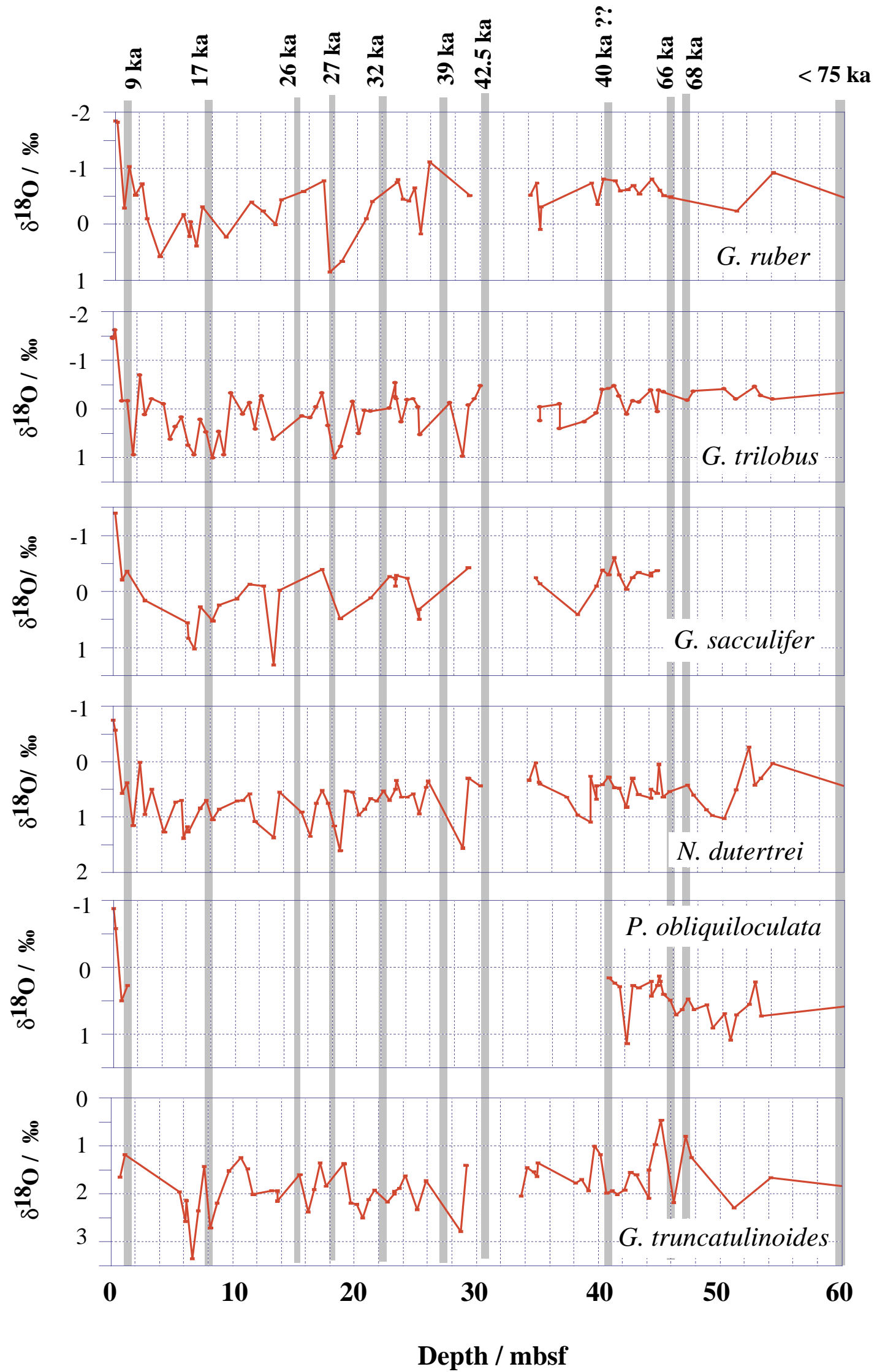

Figure 4. Planktonic foraminifer oxygen isotope records for Hole 932A for the top $60 \mathrm{mbsf}$. Age points are from the paleomagnetic-based age model (Fig. 3). 


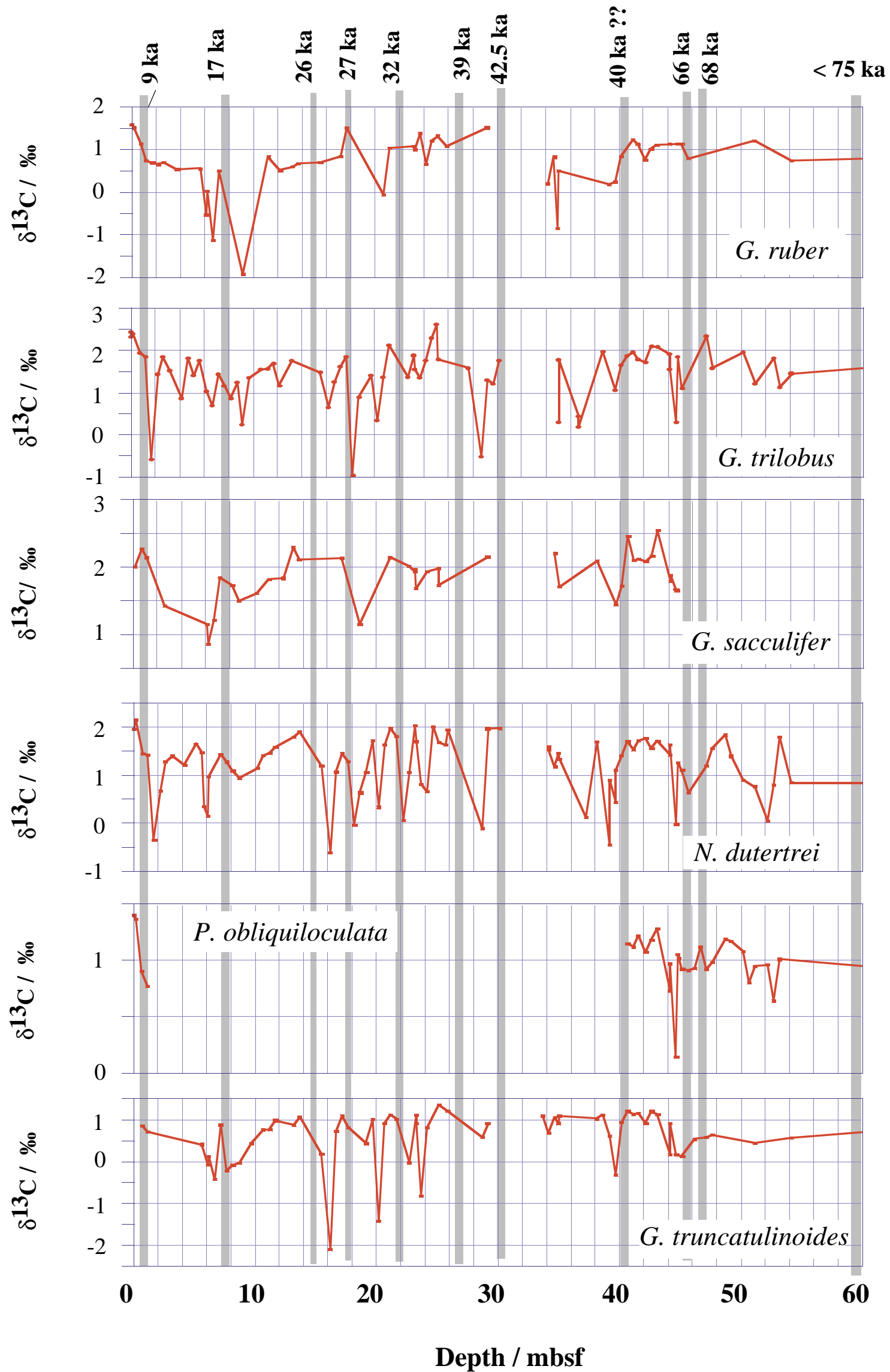

Figure 5. Planktonic foraminifer carbon isotope records for Hole 932A for the top $60 \mathrm{mbsf}$. Age points are from the paleomagnetic-based age model (Fig. 3). 
features of the planktonic carbon isotopic records (Fig. 5) are the negative excursions. One occurs at about 2 mbsf during the deglacial, seen most clearly in the G. trilobus and $N$. dutertrei records. The other is a group of excursions between 16 and 24 mbsf, and is seen most clearly in the G. truncatulinoides and $N$. dutertrei records.

\section{Site 933}

The planktonic foraminifer oxygen and carbon isotopes for Hole 933A are shown vs. depth in Figures 6-8. Fairly complete records have been obtained for five of the six isotope records for the top 35 mbsf. Below 35 mbsf, the sedimentation rates are so high that very few planktonic foraminifers were found in the normal $20-\mathrm{cm}^{3} \mathrm{sam}-$ ples. The results below 35 mbsf were obtained from the very large core-catcher samples $\left(70\right.$ to $\left.>100 \mathrm{~cm}^{3}\right)$. The top sample, at $0.21 \mathrm{mbsf}$, has an interglacial-type oxygen isotope value and represents the low sedimentation rate Holocene sediment, whereas all the other samples above the deep EMTD have heavy glacial-type oxygen isotope values (Fig. 6). The Pulleniatina obliquiloculata isotope record is curtailed by its disappearance from the equatorial Atlantic at about 40 $\mathrm{ka}$, although it reappears at about $11 \mathrm{ka}$. The glacial planktonic foraminifer oxygen isotope records do contain significant positive and negative excursions (Fig. 7). When these excursions are examined in detail (Fig. 7), it seems that all five planktonic oxygen isotope records have a positive excursion (up to $1.5 \%$ ) at $\sim 32 \mathrm{mbsf}$. In comparison, $G$. ruber and $G$. sacculifer have positive excursions at $22 \mathrm{mbsf}$, whereas G. trilobus, $N$. dutertrei, and G. truncatulinoides have negative excursions. In the case of the negative excursions, values the same as or lighter than the Holocene values occur, which would represent a massive increase in surface water temperature $\left(6.5^{\circ} \mathrm{C}\right)$ or a freshening (1.5\%o; Duplessy et al., 1992), both of which are unlikely in the western tropical Atlantic. Events of such a magnitude are not seen in the isotope records of Hole 932A, although the sedimentation rate in Hole 932A is much lower. The implied magnetic dating of these cores suggests that this excursion at 32 mbsf in Hole 933A lasted less than $500 \mathrm{yr}$. A detailed examination of the cores revealed no evidence of turbidites or other forms of reworking (Flood, Piper, Klaus, et al., 1995; R. Hiscott, pers. comm., 1995). However, this does not exclude the possibility that the samples were affected by very fine turbidites that are extremely hard to identify (Piper and Deptuck, this volume). So at present it is not known whether these excursion are real or are caused by secondary calcification and/or reworking. The opposite deviations in the records at $22 \mathrm{mbsf}$ and the values above those of the Holocene, however, strongly suggest reworking or secondary calcification.

The major feature of the Hole 933A carbon isotopic records (Fig. 8 ) is the massive negative deviation of up to $2 \%$, at $\sim 7$ mbsf. According to the age model, this is between 9 and $17 \mathrm{ka}$. This is very similar to the deviation recorded in Hole 932A, and there are no accompanying deviations in the oxygen isotope records and no sedimentological evidence to suggest that this is not a real feature.

The oxygen isotope records of planktonic foraminifers in the deep EMTD, and the underlying interglacial deposit at Site 933, are shown in Figure 6. The planktonic foraminifer oxygen isotope results indicate that the interglacial deposit has "lighter" values than the underlying glacial levee muds. However, these values do not, in general, reach the same level as the Holocene. This may indicate either that the deposit represents the very beginning or end of an interglacial period, or that there was reworking of heavier glacial material into the deposit. Maslin and Mikkelsen (this volume) have suggested that both are likely because (1) the nannofossil evidence suggest the interglacial deposit is a curtailed sequence, and (2) the reworking hypothesis is supported by the benthic foraminifer oxygen isotopes results (Vilela and Maslin, this volume), as only glacial values were recorded in the interglacial deposit. The sparsity of planktonic foraminifers in the deep EMTD means that only the isotope records of G. ruber, G. trilobus, and N. dutertrei could be generated (Figs. 6, 10). All three indicate that the foraminifers in the MTD have oxygen isotope values halfway between the Holocene and LGM values. This indicates either that the sediment from the deep EMTD was mainly formed during early oxygen Stage 3 (or any other early glacial period) when sea level was still relatively high, or that there is a lot of mixing between interglacial and glacial material within the MTD. The abyssal benthic foraminifers are absent from the deep EMTD, except for the very top, where they gave values heavier than for the LGM. Again this could reflect reworking of older material or secondary calcification of the tests.

\section{DISCUSSION \\ Deglacial Negative Carbon Isotopic Event}

Both the Site 932 and 933 planktonic foraminifer carbon isotopic records contain a significant negative deviation $\left(0.5 \% \sigma^{-2} \%\right.$ o $)$ at $\sim 12-$ 15 ka (Figs. 3, 5, 8). The average glacial-interglacial change in oceanic carbon isotope composition is $\sim 0.4 \%$ o (Maslin et al., 1995a), so the negative deviation observed in the Amazon Fan sediment must have a more local cause. There could be three possible causes of the carbon isotope event: (1) a change in surface water productivity; (2) an increase in the terrestrial organic carbon discharged by the Amazon River; or (3) significant release of gas hydrates into the water column.

The only way surface water productivity could have caused the negative carbon isotope event is if it crashed, releasing all the ${ }^{12} \mathrm{C}$ enriched organic carbon stored in the photosynthate. The diatom (Mikkelsen, this volume), nannofossil (Maslin and Mikkelsen, this volume), and planktonic foraminifer species abundance (Maslin and Mikkelsen, this volume) evidence from the Amazon Fan sediments suggests that glacial surface water productivity was extremely low, near "blue" ocean levels, and there is no evidence for radical changes. It is, therefore, difficult to conceive of a mechanism that could have reduced productivity any lower, and thus caused the isotopic event.

Another explanation for this negative deviation is an increase in the amount of "light" terrestrial organic carbon being brought into the Atlantic Ocean by the Amazon River. Bird et al. (1992) have estimated that the average isotopic content of the organic matter entering the Amazon River from the Amazon Basin is between $-27 \%$ and $-30 \%$, compared with the present surface ocean average of about $0 \%$ (Maslin et al., 1995a). If we assume that the carbon isotope shift was between $1 \%$ and $2 \%$, it would mean an average relative increase of $5 \%$ terrestrial organic matter in the water column.

To increase the relative amount of terrestrial organic matter in the water column either surface water productivity must drop, which has already been discounted, or the sediment discharge of the Amazon River must have increased. The approximate timing of the carbon isotopic event, $12-15$ calendar ka, is similar to the first major temperature increase observed in the Huascaran (Peru) ice core $\delta^{18} \mathrm{O}$ record at 13 to 15 calendar ka (Thompson et al., 1995). The increase in the Huascaran (Peru) ice core $\delta^{18} \mathrm{O}$ record also coincides with first major rise in sea level documented by Fairbanks (1989), that is, meltwater event I, suggesting a connection between the deglaciation of the Andes and the ice sheets of the Northern Hemisphere. The first stage in the deglaciation of the Andes may therefore have caused an increase in the Amazon River discharge, and thus increased the organic matter sediment load to the western equatorial Atlantic. With a temporary increase in the discharge of the Amazon River, a freshening and therefore lighter $\delta^{18} \mathrm{O}$ signal, would be expected in the Amazon Fan sediments. However, the negative carbon event seems to occur coeval with a positive deviation of the oxygen isotope records. This could be explained by the following: (1) only the sediment load of the Amazon River increased because of meltwater flushing; and/or (2) the Amazon River discharge did increase, but Sites 932 and 933 are too far away to register the effect; and/or (3) other circulation changes involving the NBCC mask the discharge signal; or (4) there was 


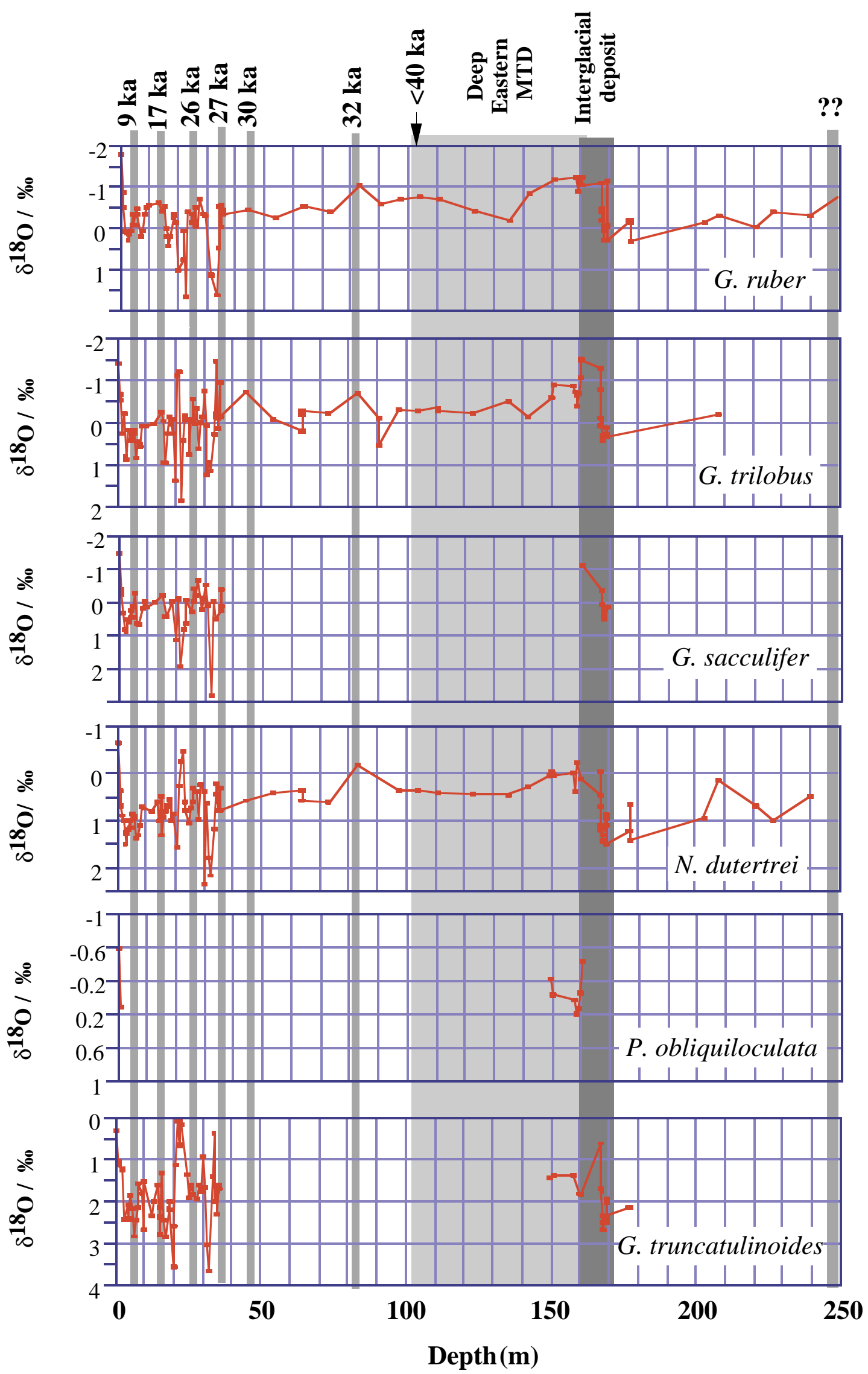

Figure 6. Planktonic foraminifer oxygen isotope records for Hole 933A. Age points are from the paleomagnetic-based age model (Fig. 3). 


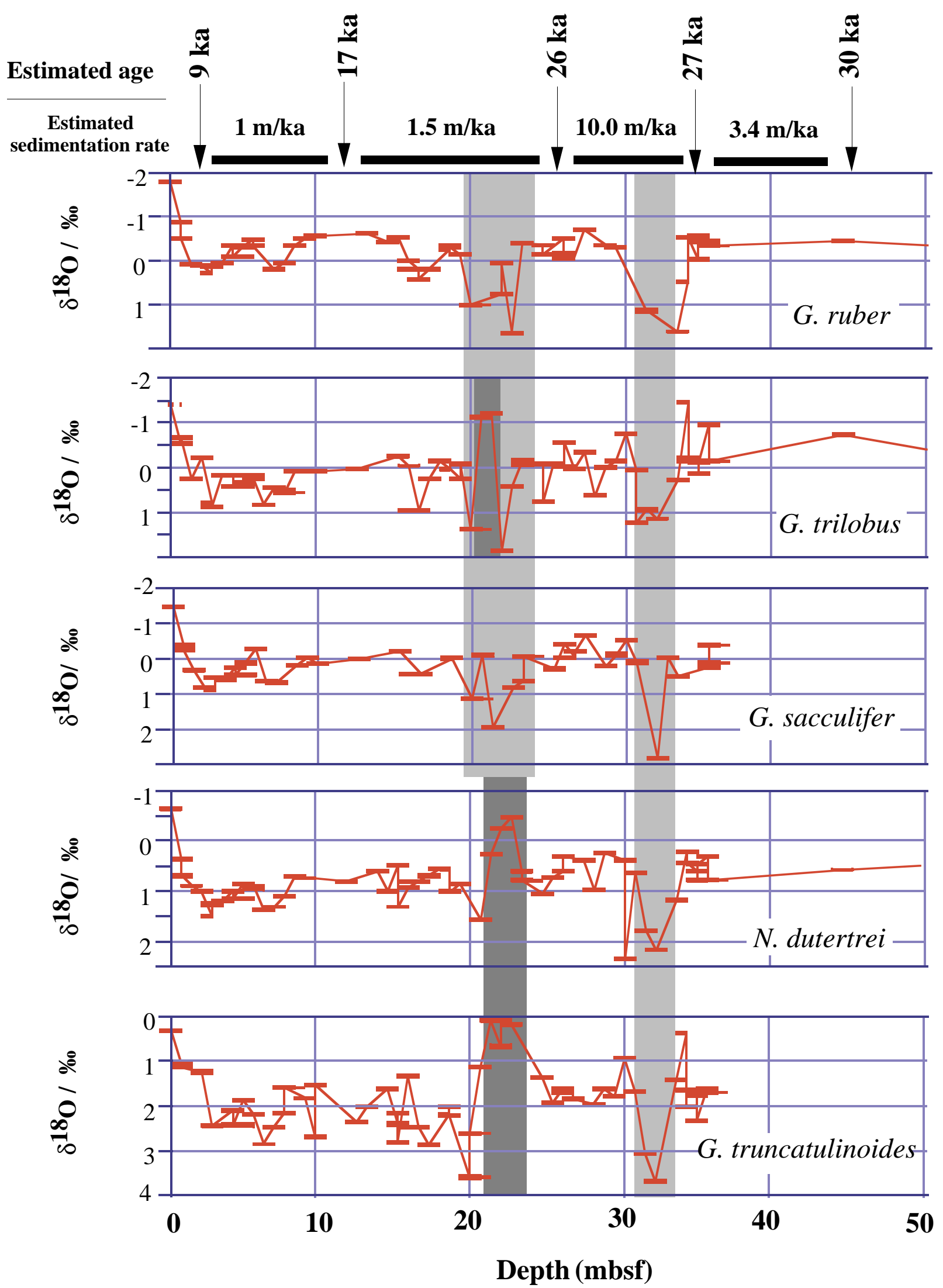

Figure 7. Planktonic foraminifer oxygen isotope records for Hole 933A for the top $50 \mathrm{mbsf}$. Age points are from the paleomagnetic-based age model (see Fig. 3 , Table 1). Lighter shaded regions indicate positive isotope deviations, whereas the dark shading indicates negative isotope deviations. 


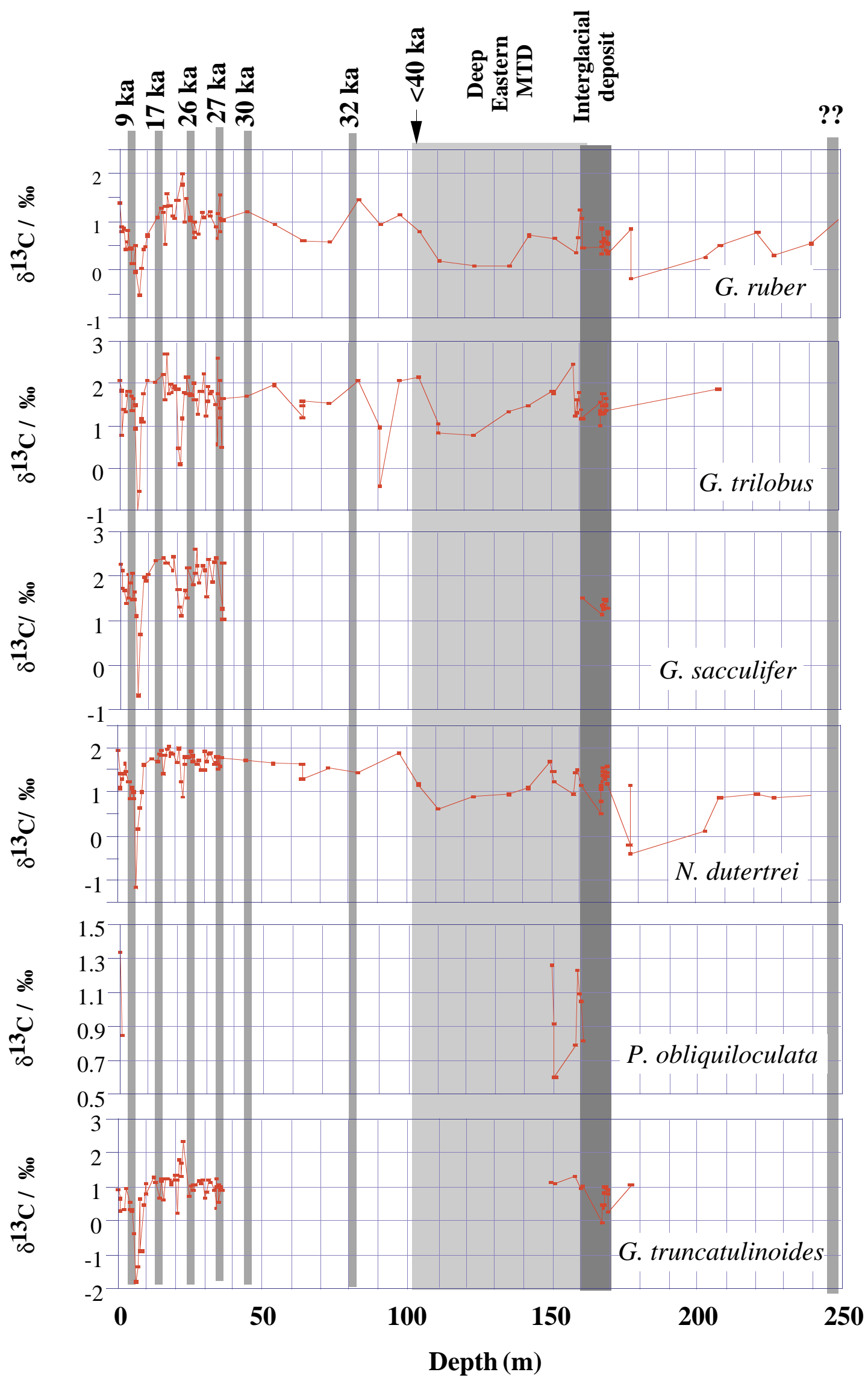

Figure 8. Planktonic foraminifer carbon isotope records for Hole 933A. Age points are from the paleomagnetic-based age model (Fig. 3). 
no increase in terrestrial organic matter discharge by the Amazon River, and the negative carbon isotope event was caused by increased gas hydrates in the water column.

The third possible cause of the negative carbon isotope event is the release of significant amounts of gas hydrates into the water column. It has been suggested by Maslin and Mikkelsen (this volume) that sea-level changes could have destabilized gas hydrate reservoirs in the Amazon Fan. Maslin and Mikkelsen (this volume) have placed the last occurrence of the near-surface Eastern and Western Debris Flows (Flood, Piper, Klaus, et al., 1995) during Termination I (13-15 calendar ka), coincidental with the carbon isotope event. The current suggestion is that sea-level rise, associated with the initial stages of the last deglaciation, destabilized the gas hydrate reservoirs and overburdened the already over-consolidated Amazon Fan sediments, causing massive failure. To give some scale of the slope failure that occurred, each one of these debris flows covers an area of up to 10,000 square miles, reaches a maximum thickness of $200 \mathrm{~m}$, and consists of approximately $5 \times 10^{4} \mathrm{Gt}$ of sediment. During the deglaciation at approximately the same time as the carbon isotope event, two of these massive failures occurred. If gas hydrates are the primary cause, then it must be considered that there are many such releases as both the Site 932 and 933 planktonic $\delta^{13} \mathrm{C}$ records show many such negative deviations. The most significant occur between about 26 and $32 \mathrm{ka}$ (Figs. 5, 8).

\section{Glacial Positive Oxygen Isotope Events}

To better assess the oxygen isotope records of Site 932, they were all combined into a composite record. This was done by removing the smaller data gaps and the inconsistencies in the sampling by applying a Gaussian interpolation using weighted duplicates with a sample spacing of $50 \mathrm{~cm}$ (same resolution as the sampling) and a window size of $150 \mathrm{~cm}$ to the isotopic records. Only the most complete oxygen isotope records were used; in the case of Site 932, this included G. ruber, G. trilobus, N. dutertrei, and G. truncatulinoides. These records were interpolated, normalized (maximum range -1 to +1 ), and then combined by averaging the four different records. The combined and normalized planktonic oxygen isotope record was placed on the Site 932 age model and is shown in Figure 9. However, it must be remembered that this record has many drawbacks. First, it has combined isotopic records of planktonic species from very different depth habitats. Thus, the inclusion of species that lie just above or within the thermocline mean that it will not be possible to monitor salinity changes at the very surface. Second, numerous data gaps occur in each of the individual records, so that events or features could be missed or artificially enhanced.

The combined record in Figure 9 indicates that there are positive oxygen isotope deviations during the last glacial. If the timing of these are compared with that of the well-known Heinrich events of the North Atlantic (Heinrich, 1988; Bond et al., 1992, 1993; Maslin et al., 1995b), then there seems to be a tentative correlation (Fig. 9). Unfortunately, the Site 932 age model and the drawbacks of the combined isotope record make it difficult to confirm such a correlation.

We suggest that if the Site 932 positive $\delta^{18} \mathrm{O}$ deviations are real features, they may have been caused by an increase in surface water salinity because of an increase in the intensity and the prolongation of the retroflection of the NBCC. The main controlling force on the direction and intensity of the NBCC is the prevailing winds (i.e., the southeast trade winds; Picaut et al., 1985; Philander and Pacanowski, 1986). At present, because of the distribution of land mass around the Atlantic, the southeasterlies push the Intertropical Convergence Zone (ITCZ) (where the southeast and northeast trade winds meet) into the Northern Hemisphere. This effect is much stronger in the summer in the Northern Hemisphere (Saha, 1973; Barry and Chorley, 1985). It is this penetration of the ITCZ into the Northern Hemisphere during the summer that drives the NBCC across the equator into becoming part of the Guyana Current, thus feeding into the Caribbean Current (Picaut et al., 1985; Philander and Pacanowski, 1986). It has been shown that the global wind system during the last glacial was more zonal because of the greater thermal gradient between the high and low latitudes (e.g., COHMAP, 1988; Lautenchlager and Herterich, 1991; Seidov and Maslin, in press). More zonal glacial southeast trades would result in the reduced penetration of the ITCZ and thus of the NBCC into the Northern Hemisphere (Fig. 1). If the NBCC was periodically prevented from entering the Northern Hemisphere, this would reduce the export of salinity and lead to heavier surface water oxygen isotopes, that is, the positive $\delta^{18} \mathrm{O}$ deviations.

We suggest that periodically the thermal gradient between the high and low latitudes increased; thus increasing the zonal component of the southeast and northeast trade winds, and reducing the northward penetration of the ITCZ. This would have curtailed the cross-equatorial export of the NBCC and may have resulted in continual NBCC-retroflection. A possible cause for this periodic increased latitudinal thermal gradient is the Heinrich events. During the Heinrich events, a huge amount of ice rafting occurs, and freshwater is released into the North Atlantic, thus chilling the surface waters as far south as $40^{\circ}-50^{\circ} \mathrm{N}$ to nearly freezing (Robinson et al., 1995; Maslin et al., 1995b).

Much more work is required on the Amazon Fan sediments to collaborate the Site 932 positive oxygen isotope deviations. Only then can the theory outlined in this study of linking the Heinrich event via the tropical wind system, to the circulation patterns of the equatorial western Atlantic, be explored in greater depth.

\section{CONCLUSIONS}

The Amazon Fan provides the opportunity to obtain the climatic records of the last glacial-interglacial cycle at a resolution approaching that of the Greenland ice cores. This preliminary study indicates that there are major drawbacks to reconstructing past climate from Fan sediments, such as reworking, and the difficulty of age modelling. It is stressed that precautions such as isotope analysis of multiple planktonic foraminifer species and detailed sedimentological work (Flood, Piper, Klaus, et al., 1995) are required if complete records are to be obtained and possible sections of reworking are to be identified. Sites 932 and 933 planktonic foraminiferal carbon isotope records have provided evidence of a distinct negative deviation during Termination I (13-15 calendar ka). We suggest that this could have been caused by an increase in the sediment discharge of the Amazon River because of the deglaciation of the Andes and/or the release of significant quantities of gas hydrates as large parts of the Amazon Fan sediment column fail because of increased sea level. Positive deviations occur in the composite Site 932 oxygen isotope record, the timing of which seem to coincide with the Heinrich events. However, there are considerable doubts over the validity of the composite record, the Site 932 age model, and the possible effects of reworking. If the positive deviations and this tentative correlation with Heinrich events are confirmed, we suggest that the deviations may be caused by an almost permanent retroflection of the North Brazilian Coastal Current.

\section{ACKNOWLEDGMENTS}

The authors are grateful for the help and support of M. Sarnthein, N. Mikkelsen, and N. Shackleton. We gratefully acknowledge the cooperation of $\mathrm{H}$. Cordt, who supervised the operation of the mass spectrometer in Kiel. The Deutsche Förschungsgemeinschaft is thanked for supporting this study. We also wish to thank the reviewers. 
North East Atlantic

Lithic fragment content $(\%)$

BOFS 5K (Maslin et al., 1995b)
ODP Leg 155 Site 932

\section{Combined and Normalized Planktonic}

Foraminifer Oxygen isotopes

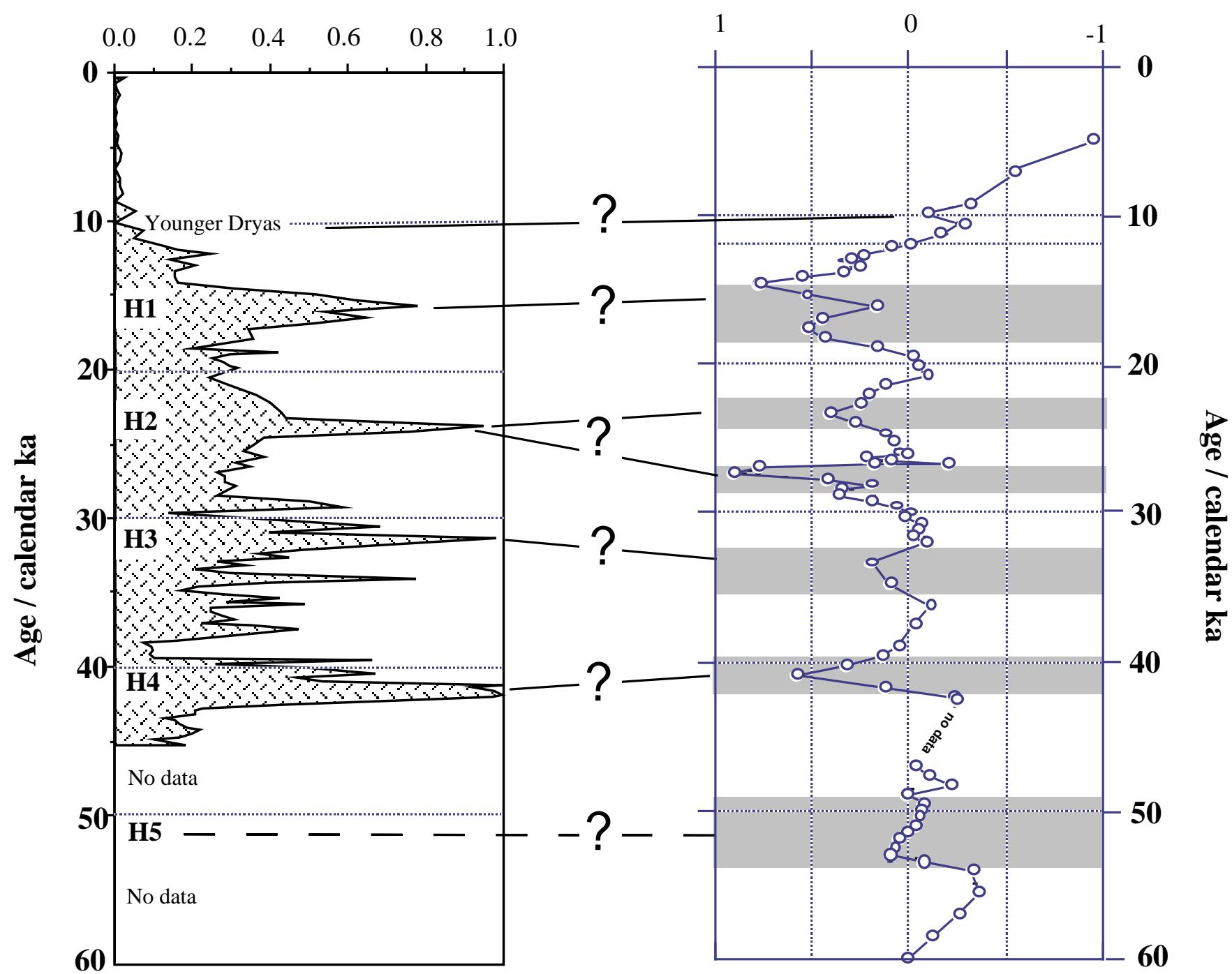

Figure 9. Comparison of the combined, normalized, planktonic foraminifer oxygen isotope records from Hole 932A, with the Heinrich events. The Heinrich events are illustrated by the percentage lithic content of the coarse fraction $(>63 \mu \mathrm{m})$ of Core BOFS $5 \mathrm{~K}\left(50^{\circ} 41.3^{\prime} \mathrm{N}, 21^{\circ} 51.9^{\prime} \mathrm{W}\right.$, water depth $3547 \mathrm{~m}$; McCave, 1989), which indicates when there was a significant increase in the amount of ice-rafted debris being deposited in the North Atlantic (Maslin et al., 1995b). Unfortunately, this record only covers the last $45 \mathrm{ka}$; the timing of Heinrich event 5 is taken from Bond et al. (1992, 1993).

\section{REFERENCES}

Barry, R.G., and Chorley, R.J., 1985. Atmosphere, Weather and Climate: London (Methuen and Co.).

Bird, M.I., Fyfe, W., Pinheiro-Dick, D., and Chivas, A.R., 1992. Carbon isotope indicators of catchment vegetation in the Brazilian Amazon. Global Biogeochem. Cycles, 6:293-306.

Bond, G.C., Broecker, W., McManus, J., Labeyrie, L., Jouzel, J., Bonani, G., 1993. Correlations between climate records from North Atlantic sediments and Greenland ice. Nature, 365:143-147.

Bond, G., Heinrich, H., Broecker, W., Labeyrie, L., McManus, J., Andrews, J., Huon, S., Janitschik, R., Clasen, S., Simet, C., Tedesco, K., Klas, M., Bonani, G., and Ivy, S., 1992. Evidence for massive discharge of icebergs into the North Atlantic ocean during the last glacial period. Nature, 360:245-249.
Carneiro de Castro, J., Miura, K., and Estrela-Braga, J.A., 1978. Stratigraphic and structural framework of the Foz do Amazonas Basin. Proc. Annu. Offshore Techno. Conf., 3:1843-1848.

Cisowski, S.M., 1995. Synthesis of magnetic remanence correlation, Leg 155. In Flood, R.D., Piper, D.J.W., Klaus, A., et al., Proc. ODP, Init. Repts., 155: College Station, TX (Ocean Drilling Program), 701-702.

COHMAP Members, 1988. Climatic changes of the last 18,000 years: observations and model simulations. Science, 241:1043-1052.

Curry, W.B., Shackleton, N.J., Richter, C., et al., 1995. Proc. ODP, Init. Repts., 154: College Station, TX (Ocean Drilling Program).

Damuth, J.E., 1975. Quaternary climate change as revealed by calcium carbonate fluctuations in western equatorial Atlantic sediments. Deep-Sea Res. Part A, 22:725-743.

1977. Late Quaternary sedimentation in the western equatorial Atlantic. Geol. Soc. Am. Bull., 88:695-710. 
Damuth, J.E., and Fairbridge, R.W., 1970. Equatorial Atlantic deep-sea arkosic sands and ice-age aridity in tropical South America. Geol. Soc. Am. Bull., 81:189-206.

Damuth, J.E., and Kumar, N., 1975. Amazon cone: morphology, sediments, age and growth pattern. Geol. Soc. Am. Bull., 86:863-878.

Damuth, J.E., Flood, R.D., Knowsmann, R.O., Belderson, R.H., Gorini, M.A., 1988. Anatomy and growth patterns of Amazon deep-sea fan as revealed by long-range side-scan sonar (GLORIA) and high-resolution seismic studies. AAPG Bull., 72:885:911.

Dansgaard, W., Johnsen, S.J., Clausen, H.B., Dahl-Jensen, D., Gundestrup, N.S., Hammer, C.U., Hvidberg, C.S., Steffensen, J.P., Sveinbjörnsdottir, A.E., Jouzel, J., and Bond, G., 1993. Evidence for general instability of past climate from a 250-kyr ice-core record. Nature, 364:218-220.

Duplessy, J.-C., Labeyrie, L., Arnold, M., Paterne, M., Duprat, J., and van Weering, T., 1992. Changes in surface water salinity of the North Atlantic Ocean during the last deglaciation. Nature, 358:485-488.

Fairbanks, R.G., 1989. A 17,000-year glacio-eustatic sea level record: influence of glacial melting rates on the Younger Dryas event and deep-ocean circulation. Nature, 342:637-642.

Flood, R.D., Piper, D.J.W., and Shipboard Scientific Party, 1995. Introduction. In Flood, R.D., Piper, D.J.W., Klaus, A., et al., Proc. ODP, Init. Repts., 155: College Station, TX (Ocean Drilling Program), 5-16.

Flood, R.D., Piper, D.J.W., Klaus, A., et al., 1995. Proc. ODP, Init. Repts., 155: College Station, TX (Ocean Drilling Program).

Heinrich, H., 1988. Origin and consequences of cyclic ice rafting in the northeast Atlantic Ocean during the past 130,000 years. Quat. Res., 29:142-152.

Hoorn, C., Guerrero, J., Sarmiento, G., and Lorente, M., 1995. Andean tectonic as a cause for changing drainage patterns in Miocene northern South America. Geology, 23:237-240.

Lautenschlager, M., and Herterich, K., 1991. Atmospheric response to Ice Age conditions: climatology near the earth's surface. J. Geophys Res., 95:22547-22557.

Levitus, S., 1982. Climatological Atlas of the World Ocean. NOAA Prof. Pap., 13.

Manley, P.L., and Flood, R.D., 1988. Cyclic sediment deposition within the Amazon deep-sea fan. AAPG Bull., 72:912-925.

Maslin, M.A., Adams, J., Thomas, E., Faure, H., and Haines-Young, R., 1995a. Estimating the carbon transfer between the oceans, atmosphere and the terrestrial biosphere since the last glacial maximum. Terra Nova, 7: $358-366$

Maslin, M.A., Shackleton, N., and Pflaumann, U., 1995b. Surface water temperature, salinity and density changes in the N.E. Atlantic during the last 45,000 years: Heinrich events, deep water formation and climatic rebounds. Paleoceanography, 10:527-544.

McCave, I.N., 1989. RRS Discovery 184 BOFS 1989 Leg 3 Cruise Report. Univ. of Cambridge.

McHargue, L.R., Damon, P.E., and Donahue, D.J., 1995. Enhanced cosmicray production of $10 \mathrm{Be}$ coincident with the Mono Lake and Laschamp geomagnetic excursions. Geophys. Res. Lett., 22:659-662.
Merrill, R.T., and McElhinny, M.W., 1983. The Earth's Magnetic Field: Its History, Origin, and Planetary Perspective: London (Acad. Press).

Metcalf, W.G., and Stalcup, M.C., 1967. Origin of the Atlantic Equatorial Undercurrent. Deep-Sea Res., 72:4959-4975.

Nittrouer, C.A., and DeMaster, D.J., 1986. Sedimentary processes on the Amazon continental shelf: past, present and future research. Cont. Shelf Res., 91:537-550.

Philander, S., and Pacanowski, R., 1986. A model of the seasonal cycle in the tropical Atlantic Ocean. J. Geophys. Res., 91:192-206.

Picaut, J., et al., 1985. Climatic Atlas of the Tropical Atlantic Wind Stress and Sea Surface Temperature 1964-1979: Honolulu (Univ. of Hawaii Press).

Prell, W.L., and Damuth, J.E., 1978. The climate related diachronous disappearance of Pulleniatina obliquiloculata in Late Quaternary sediments of the Atlantic and Caribbean. Mar. Micropaleontol., 3:267-277.

Richardson, P., and Walsh, D., 1986. Mapping climatological seasonal variations of surface currents in the tropical Atlantic using ship drifts. J. Geophys. Res., 91:537-550.

Robinson, S.G., Maslin, M.A., and McCave, I.N., 1995. Magnetic susceptibility variations in late Pleistocene deep-sea sediments of the N.E. Atlantic: implications for ice-rafting and paleocirculation at the last glacial maximum. Paleoceanography, 10:221-250.

Saha, R.R., 1973. Global distribution of double cloud banks over the tropical oceans. Q. J. R. Meteorol. Soc., 99:551-555.

Sarnthein, M., Winn, K., Jung, S., Duplessy, J.-C., Labeyrie, L., Erlenkeuser, H., and Ganssen, G., 1994. Changes in East Atlantic deep-water circulation over the last 30,000 years: eight-time-slice reconstructions. Paleoceanography, 9:209-267.

Seidov, D., and Maslin, M.A., in press. Seasonally ice free glacial Nordic Seas without deep water ventilation. Terra Nova

Showers, W.J., and Bevis, M., 1988. Amazon Cone isotopic stratigraphy: evidence for the source of the tropical meltwater spike. Palaeogeogr., Palaeoclimatol., Palaeoecol., 64:189-199.

Thompson, L.G., et al., 1995. Late glacial stage and Holocene tropical ice core records from Huascaran, Peru. Science, 269:46-50.

Trauth, M., 1995. Bioturbate Signalverzerrung hockauflosender paläoozeanographischer Zeitreihen (Bioturbational signal distortion of high-resolution paleoceanographic time-series) [Ph.D. thesis]. Geol.-Paleaontol. Inst., Univ. Kiel.

Tric, E., Valet, J.-P., Tucholka, P., Paterne, M., Labeyrie, L., Guichard, F., Tauxe, L., and Fontugne, M., 1992. Paleointensity of the geomagnetic field during the last 80,000 years. J. Geophys. Res., 97:9337-9351.

Date of initial receipt: 5 December 1995

Date of acceptance: 6 June 1996

Ms 155SR-221 